\title{
UTM Postgraduate Students' Perspective on Feedback Practices in Higher Education
}

\author{
Rohaya Talib ${ }^{1}$, Hamimah Abu Naim ${ }^{1} \&$ Hawa Syamsina Md Supie ${ }^{1}$ \\ ${ }^{1}$ Faculty of Education, Universiti Teknologi Malaysia, Malaysia \\ Correspondence: Hawa Syamsina Md Supie, Faculty of Education, Universiti Teknologi Malaysia, 81300 Skudai, \\ Johor Bahru, Johor, Malaysia. Tel: 60-16-665-0745. E-mail: h_syamsina@yahoo.com
}

Received: November 2, 2014 Accepted: March 13, 2015 Online Published: June 25, 2015

doi:10.5539/ies.v8n13p17 URL: http://dx.doi.org/10.5539/ies.v8n13p17

\begin{abstract}
Assessment Feedback (AFB) is one of the most potent influences on student's learning and achievement as it enables postgraduate students to restructure understanding and develop powerful ideas to meet Higher Education (HE) standard. A focus on AFB practices among the lecturers from postgraduate students' perspective is pertinent in enhancing retention and completion of research studies. Thus, this prelim study investigates mean differences and interactions of AFB practices on three dimensions (Timeliness, Meaningfulness, Specificity) in relation to gender, Mode of Study and Field of Study. A sample of 37 postgraduate students who engaged in research studies in UTM was selected as respondents. Assessment Feedback Practices Inventory (AFBI) was analyzed using the Rasch Measurement Model for item reliability (.96). The data were analyzed using descriptive (mean and standard deviation) and inferential statistics (Spearman rho correlation coefficient). It was found that $\mathrm{AFB}$ practices were at the highest level for Meaningfulness $(\mathrm{M}=4.69, \mathrm{SD}=.75)$ followed by Timeliness $(\mathrm{M}=4.04, \mathrm{SD}=.53)$, and Specificity $(\mathrm{M}=3.88, \mathrm{SD}=.55)$. AFB forms practiced among lecturers resulted in verbal form $(\mathrm{M}=2.80, \mathrm{SD}=1.27)$ being practiced more than the written form $(\mathrm{M}=2.48, \mathrm{SD}=.63)$. For the AFB preference, results showed that $81.1 \%$ of the students preferred the feedback in both, verbal and written form, whereas $10.8 \%$ prefers verbal, and $8.1 \%$ prefers written form. However, the results showed weak relationship between AFB and gender, Mode of Study and Field of Study. It is suggested that an assessment feedback manual should be developed.
\end{abstract}

Keywords: formative assessment, assessment feedback, higher education, meaningful feedback, specific feedback

\section{Introduction}

Despite of the upsurge education improvement made through Malaysia Education Blueprint 2013-2025, the education system remains committed to developing students holistically; intellectually, spiritually, emotionally, and physically. The blueprint is a review done on Malaysia's education system in order to improve the system better. The standard of students is set to have impact by encouraging students in shaping their own learning experience.

Constructivism is a learning theory which emphasizes on problem-solving and understanding. It requires the use of authentic tasks, experiences, settings, and assessments (Christie, 2005). In addition, more experiences on students' learning development courses of action can additionally originate from examinations and meetings with learners. Thus, the research work course allows students to have a lot control over their own learning and the opportunity given to negotiate content, assignments, procedures, and deadlines which are similar to a Constructivist course (Vrasidas, 2000). Furthermore, by involving in their research work, the students are experiencing learning rather than engaging solely on assessment and testing. The discussion between the students and lecturers could have concluded both the active and social aspect of the roles of learners in Constructivism.

Constructivism extends the students' learning process beyond the content presented to them in the teaching process. In other words, the emphasis shifts from teaching to learning. Constructivist suggests that it is particularly indispensable that in light of feedback, students be swayed to persistently build and remake their information, to advance and change their understandings (Swan, 2005). The expression "scaffolding" was produced as an illustration to depict the kind of aid offered by an instructor or companion to help learning. In the 
process of scaffolding, the lecturer helps the students to master a task or concept that the student is initially unable to grasp independently (Wood, Bruner, \& Ross, 1976). It intends to allow students to complete as much of the task as possible unassisted.

In the sociocultural viewpoint, scaffolding is a communicative cooperative process and it includes arrangement of importance in the middle of lecturers and learners about expectations and how best to enhance the execution of tasks (Spiller, 2009). Scaffolding refers to the particular kind of help, assistance and support that enables a student to do a task which they cannot quite manage on their own and which brings them closer to a state of competence that will enable them to carry out other similar tasks independently in the future (Maybin, Mercer, \& Stierer, 1992). Shepard (2005) stated that Scaffolding also refers to support that educators provide to the learner during problem solving- in the form of reminders, hints, and encouragement to ensure a successful completion of a task.

Scaffolding is closely related to Vygotsky's Zone of Proximal Development (ZPD). ZPD is characterized as the separation between the real formative level as dictated by autonomous critical thinking and the level of potential advancement as decided through critical thinking under adult direction or as a team with more competent companions (Vygotsky, 1978). According to ZPD, students need to collaborate with others to reach a higher level of development. This is when the teacher's guidance is needed in the form of scaffolding.

Sadler (2005) defined assessment as the procedure of making judgment about the quality and degree of students' accomplishment or execution, and consequently by induction a judgment about the learning which has occurred. Most of the time, judgment is made based on specified tasks or works which has to be submitted to attain appraisal or judging. Assessment more often than not is defined as our previous practices, but not by what is demanded and needed currently. We always associate assessment with examinations and we don't really assess whether the students are really learning as in constructing their own knowledge or just merely rote learning. Assessment feedback is also a part of scaffolding since it provides information for the improvement and construction of knowledge assessment feedback, an information which comes in various forms with the purpose of motivating the students by informing how well they have done and how to improve.

Assessment feedback should play its role in the learning process in order to improve on the teaching and learning process. Assessment feedback can be either formative or summative. Formative feedback is when students use the information to enhance learning and for the lecturers to re-align their teaching, whereas, summative feedback is used to sum up the final judgment on students' work (Rosiatimah \& Mohd-Afiq, 2013). Assessment feedback also helps students to polish skills like decision-making, critical thinking, and problem-solving. It is inevitably needed for a good teaching and learning process to take place. Hence, it is beneficial to consider the practice of assessment feedback among postgraduate students.

\subsection{Background of Study}

Assessment feedback is a crucial part in the teaching and learning cycle. However, both lecturers and students feel disappointed due to the unclear and sometimes demoralizing assessment feedback. Swan (2005) specified that even though feedback is given, it may lack of guidance on how to improve it. Feedback can be given in the form of verbal or written comments. Verbal comments can be done through personal conversations while written comments are those written on drafts and assignment papers or via e-mails responding to proposals or introductions (Swan, 2005). However, it is common that students do not read the lecturer's feedback comment (Duncan, 2007).

Students request criticism basically on the grounds that they had put much exertion in their work. In this way, their mentors need to endeavor too in giving input. They needed the mentors to highlight their qualities and shortcomings in their work and give remarks to future direction (Higgins, Hartley, \& Skelton, 2002).Other than improvement in performance, motivation has also been identified as the important part of the feedback process. They also reported that in the study done, students received experienced feedback which provides clarification and enhances their motivation. In a study done, it was found that most of the university tutors agreed that feedback need to be specific and detailed (Beaumont, O'Doherty, \& Shannon, 2011).

Therefore, the standard of students in higher education can be achieved by the practice of assessment feedback. While quality feedback is perceived as having both written and verbal provided within the context. All the university tutors agreed that, feedback a continuous dialogue within a cyclical assessment. The issue of feedback quality remains a major concern for higher education institutions. According to Beaumont et al. (2011), feedback quality has consistently received the lowest satisfaction in the UK National Student Survey for five consecutive years with 2009 recorded less than $55 \%$ of the respondents agreed that feedback had been detailed, prompt or helped clarify understanding. 
Evans (2013) stated that only 4\% articles' central focus was on individual learning needs, including aspects such as gender, culture, learning styles, and how individuals make sense and use feedback. The literature done through ScienceDirect, MyTO, Taylor, and other related databases show little findings on assessment feedback done quantitatively among postgraduate students and non-specific on language learning. It is reported that the utility of tutors' feedback comments, the meaning and impact of assessment feedback for students that still remains under-researched, particularly from the students' perspectives (Higgins et al., 2002).

A recent study by the Ministry of Higher Education (SETARA, 2009) shows that students yearn for more and quality feedback, but lecturers at the university are often too busy which arises complaints from the students that the lecturers tend to be unapproachable and unconcern. Locally, there was also a case study of feedback in higher education was done with the aim to improve the quality of feedback and thus students' learning (Tamby \& Halim, 2011).

\subsection{Statement of Problem}

One of the factors which seem to be of great importance in dealing with feedback is that it helps students to reconstruct their knowledge or skill what is desired (Maryan, Seyyed, \& Maryam, 2013). It is crucial to look at assessment feedback desired and perceived by the students themselves.

The purpose of the study is to investigate the perception of postgraduate UTM students on assessment feedback. The researcher also seeks to determine the form of assessment feedback practiced among postgraduate and their preferences and also its relationship along the three factors which are gender, mode of study and field of study.

\subsection{Objectives of Study}

The objectives of the study are; 1) to identify the perception UTM postgraduate students towards assessment feedback from three important dimensions in their research study, 2) to investigate the form of assessment feedback practised by postgraduate students' supervisors in the form of verbal, written, or both, 3) to investigate the preference of assessment feedback form among postgraduate students, and 4) to investigate the relationship between the postgraduate students' perceptions factors; Gender, Mode of Study and Field of Study.

\section{Method}

The researcher utilized cross-sectional survey design. This design is suitable for a large-scale assessment and appropriate for examining current attitudes, beliefs, opinions, or practices (Creswell, 2008). A set of questionnaire was developed and distributed to 37 respondents.

The population for this study consists of 9760 postgraduate students of Universiti Teknologi Malaysia, Skudai. This research employs the multi-stage cluster sampling method whereby the researcher at first narrowed down the population from 13 faculties according to their field of study, namely; Social Science, Engineering, and Science and Technology. The respondents of this study were students who enrolled for their research study or dissertation for Semester 2 2013/2014. They were chosen on the basis that they are engaged with AFB throughout the research study or dissertation completion. The total number of samples for this preliminary study is 37 respondents.

A set of questionnaire which consists of 37 questions was developed based on the objectives of the study. The researcher has removed the neutral point which is usually labeled as "unsure", "uncertain", or "neither". The questionnaire was divided into five sections;1) Section A: Demographic, 2) Section B: Perception on Assessment Feedback(6-point Likert-type Scale), 3) Section C: Assessment Feedback Practised by Supervisors(Frequency Scale), and 4) Section D: Preferences on Assessment Feedback(Closed Format Question). The researcher consulted panel experts to ensure the content validity. Then, the researcher utilized Rasch's Winstep software for item reliability and obtained a value of .96.Five items were found as misfit items and omitted from the inventory. The item in fit MNSQ is ranged between .55-1.45.

Then, the data were further analyzed using SPSS statistical software for descriptive and inferential analysis. The data were analyzed for mean and standard deviation. As for inferential statistics, the Spearman rho correlation coefficient was applied.

\section{Results}

This study found that AFB practices were at the highest level for Meaningfulness $(\mathrm{M}=4.69, \mathrm{SD}=.75)$ followed by Timeliness $(\mathrm{M}=4.04, \mathrm{SD}=.53)$, and Specificity $(\mathrm{M}=3.88, \mathrm{SD}=.55)$. This finding supports what was reported, that feedback must be specifically explained and meaningful in a way that future work is suggested for improvements (Higgins et al., 2002). The results indicated that the AFB perceived by the students is valued as meaningful which assisted them to make improvements. This finding also suggests that the lecturers focus more 
on what the students have done wrong rather than explaining their misconceptions for further improvements. In addition, the lecturers do not face any difficulties in providing AFB in time for the students to make corrections.

As for AFB forms practiced among lecturers, it was found that the verbal form $(\mathrm{M}=2.80, \mathrm{SD}=1.27)$ is practiced more compared to the written form $(\mathrm{M}=2.48, \mathrm{SD}=.63)$. Based on the frequency scale, the mean for both verbal and written is practiced as "sometimes". It is presumed that lecturers and students discusses AFB more orally on a meeting basis or via phone calls rather than providing AFB in written form such as e-mails, notes, attachments in social media, and so on. Besides that, verbal feedback is less time-consuming and much more convenient. This agrees to a study conducted which was done by the observation that students are having problems to understand feedback. Blair and McGinty (2010) discovered that effort-wise, oral feedback is preferred by the lecturers since it is less time consuming compared to a detailed written feedback.

Then, it was found that $81.1 \%$ prefers the feedback to be in both, verbal and written form. Another $10.8 \%$ prefers verbal, whereas a total of $8.1 \%$ prefers the feedback to be in written form. Referring to the results that shows the written form and verbal is practiced almost equally, it is parallel to what they preferred to have as both forms of feedback. This could be caused by during the consultation sessions, the lecturers provided both forms of feedback simultaneously and not in isolation.

Table 1. Correlation between AFB and gender, mode of study and field of study

\begin{tabular}{lccccc}
\hline & & Gender & Field of Study & \multicolumn{2}{c}{ Mode of Study } \\
\hline \multirow{3}{*}{ Spearman's rho } & \multirow{2}{*}{ AFB mean } & Correlation Coefficient & .058 & .278 & .212 \\
& & Sig. (2-tailed) & .731 & .096 & .207 \\
\hline
\end{tabular}

However, there is a weak relationship between AFB and Mode of Study and Field of Study. The AFB and Field of Study are weakly correlated as shown in Table 1 which depict, $r(36)=.28, p>.05$. Table 1 also shows that the AFB is weakly correlated with Mode of Study, $r(36)=.21, p>.05$. This shows that Field of Study and Mode of Study is somehow related to AFB. This result also indicated that there might be a difference in the way that AFB provided among different FOS and MOS. Full research students might experience more meetings with their lecturers compared to the coursework students as the credit weightage differs from one another. While, AFB provided differs among FOS possibly because engineering and science and technology needed more AFB to work on their project. However, AFB has a very weak relationship with gender, $r(36)=.06, p>.05$. This result reported that the relationship is very weak with almost no relationship indicated. This perhaps depicts no biasness in the AFB provided by the lecturers to the students of different genders.

\section{Discussion}

The survey illustrates UTM postgraduates' perceptions on assessment feedback. From the responds, it can be concluded that students need meaningful, timely and specific assessment feedback to assist them with the completion of their research work. An assessment feedback with the three dimensions mentioned is committedly agreed with the students as part of a quality feedback. The students also value both verbal and written forms of feedback practiced by their lecturers, but they prefer to receive both forms of AFB. AFB received by the students is also affected by their mode of study and field of study. This finding can benefit the academicians for improvement as it reveals the valued assessment feedback. It is also suggested that an assessment feedback standard manual should be developed to further assist the students and also to ensure that they receive a quality assessment feedback.

\section{Acknowledgements}

The authors wish to thank the Ministry of Education, Universiti Teknologi Malaysia and Universiti Teknologi MARA for the support. A special thanks too is dedicated to School of Postgraduate Studies, UTM for their assistance in providing the data needed for this study. Comments by two anonymous reviewers also significantly helped to improve an earlier version of this manuscript.

\section{References}

Beaumont, C., O’Doherty, M., \& Shannon, L. (2011). Reconceptualising assessment feedback: A key to improving student learning? Studies in Higher Education, 36(6), 671-687. http://dx.doi.org/10.1080/03075071003731135 
Blair, A., \& McGinty, S. (2010). It's good to talk? developing feedback practices. Gateway Journal, 1, 18-26.

Christie, A. (2005). Constructivism and its implications for educators. Retrieved February 19, 2014, from $\mathrm{http} / / /$ alicechristie.com/edtech/learning/constructivism/index.htm

Creswell, J. W. (2008). Educational Research: Planning, conducting, and evaluating quantitative and qualitative research. Malaysia: Pearson Education.

Duncan, N. (2007). Feed-forward: Improving students' use of tutor comments. Assessment \& Evaluation in Higher Education, 3, 271-283. http://dx.doi.org/10.1080/02602930600896498

Evans, C. (2013). Making sense of assessment feedback in higher education. Review of Educational Research, 83(1), 70-120. http://dx.doi.org/10.3102/0034654312474350

Higgins, R., Hartley, P., \& Skelton, A. (2002). The conscientious consumer: Reconsidering the role of assessment feedback in student learning. Studies in Higher Education, 27(1), 53-64. http://dx.doi.org/10.1080/03075070120099368

Maryan, B., Seyyed, H., \& Maryam, S. (2013). Peer feedback in learning English writing: Advantages and disadvantages. Journal of Studies in Education, 3, 91-97. http://dx.doi.org/10.5296/jse.v3i4.4314

Maybin, J., Mercer, N., \& Stierer, B. (1992). Scaffolding learning in the classroom. In K. Norman (Ed.), Thinking Voices: The Work of the National Oracy Project Hodderand Stoughton. London.

Rosiatimah, M. I., \& Mohd-Afiq, A. (2013). Assessment feedback to accounting students. Procedia-Social and Behavioral Sciences, 90, 651-659. http://dx.doi.org/10.1016/j.sbspro.2013.07.137

Sadler, D. R. (2005). Interpretation of Criteria-based Assessment and Grading in Higher Education. Assessment and Evaluation in Higher Education, 30(2), 175-194. http://dx.doi.org/10.1080/0260293042000264262

Shepard, L. A. (2005). Linking formative assessment to scaffolding. Assessment to Promote Learning, 63, 66-70.

Spiller, D. (2009). Assessment: Feedback to promote student learning. Retrieved February 19, 2014, from http://www.waikato.ac.nz/tdu/pdf/booklets/6_AssessmentFeedback.pdf

Swan, K. (2005). A constructivist model for thinking about learning online. In J. Bourne, \& J. C. Moore (Eds), Elements of Quality Online Education: Engaging Communities. Needham, MA: Sloan-C.

Tamby, S. M. M., \& Halim, L. (2011). Improve feedback on Teaching and Learning at the University through Peer Group. Procedia-Social and Behavioral Sciences, 18, 633-637. http://dx.doi.org/10.1016/j.sbspro.2011.05.093

Vrasidas, C. (2000). Constuctivism versus objectivism: Implications for interaction, course design, and evaluation in distance education. International Journal of Educational Telecommunications, 6(4), 339-362.

Vygotsky, L. (1978). Mind and Society. Cambridge: Harvard University Press.

Wood, D., Bruner, J., \& Ross, G. (1976). The role of tutoring in problem-solving. Journal of Scaffolding children's talk and learning. Child Psychology and Psychiatry, 17, 89-100. http://dx.doi.org/10.1111/j.1469-7610.1976.tb00381.x

\section{Copyrights}

Copyright for this article is retained by the author(s), with first publication rights granted to the journal.

This is an open-access article distributed under the terms and conditions of the Creative Commons Attribution license (http://creativecommons.org/licenses/by/3.0/). 